\title{
Identification of Nutritional Targets in Spanish Children Belonging to the LAyDI Cohort for the Development of Health Promotion Strategies in the First Two Years of Life
}

\author{
María Gómez-Martín ${ }^{1,2}(\mathbb{D})$, Begoña Domínguez ${ }^{3,4}\left(\mathbb{D}\right.$, Miguel Gueimonde ${ }^{2,5}$ (D) and Sonia González ${ }^{1,2, *(\mathbb{D})}$ \\ 1 Area of Physiology, Department of Functional Biology, Faculty of Medicine, University of Oviedo, \\ Julián Claveria, 33006 Oviedo, Spain; gomezmarmaria@uniovi.es \\ 2 Group Diet, Microbiota and Health, Instituto de Investigaciones Sanitarias del Principado de Asturias (ISPA), \\ Avd. Roma, 33011 Oviedo, Spain; mgueimonde@ipla.csic.es \\ 3 Group Comprehensive Approach to Childhood Overweight, Instituto de Investigaciones Sanitarias del \\ Principado de Asturias (ISPA), Avd. Roma, 33011 Oviedo, Spain; begoa.dominguez@gmail.com \\ 4 Spanish Association of Primary Care Pediatrics (AEPap), Avda. de Burgos, 28036 Madrid, Spain \\ 5 Department of Microbiology and Biochemistry of Dairy Products, Instituto de Productos Lácteos de Asturias, \\ Consejo Superior de Investigaciones Científicas (IPLA-CSIC), Paseo Río Linares, 33300 Villaviciosa, Spain \\ * Correspondence: soniagsolares@uniovi.es; Tel.: +34-985-104-209
}

check for updates

Citation: Gómez-Martín, M.; Domínguez, B.; Gueimonde, M.; González, S. Identification of Nutritional Targets in Spanish Children Belonging to the LAyDI Cohort for the Development of Health Promotion Strategies in the First Two Years of Life. Int. J. Environ. Res. Public Health 2021, 18, 939. https: / / doi.org/10.3390/ ijerph18030939

Received: 11 December 2020

Accepted: 19 January 2021

Published: 22 January 2021

Publisher's Note: MDPI stays neutral with regard to jurisdictional claims in published maps and institutional affiliations.

Copyright: (c) 2021 by the authors. Licensee MDPI, Basel, Switzerland. This article is an open access article distributed under the terms and conditions of the Creative Commons Attribution (CC BY) license (https:// creativecommons.org/licenses/by/ $4.0 /)$.

\begin{abstract}
The first 1000 days of life seem to represent the temporal window of opportunity for modulating some of the risk factors associated with the later development of pathologies. Nonetheless, the dietary pattern and nutritional status of children receiving complementary feeding is still understudied. We aimed to assess the food intake in children from the LAyDI cohort (Spain) at 18 and 24 months of age and evaluate this in relation to nutrient requirements and bioactive compound consumption. This was a prospective and multicenter study analyzing information from administered questionnaires about general characteristics and food frequency consumption in 426 children of 18 months and 336 of 24 months. The observed intake of vegetables, fruits, dairy, and eggs was lower than the recommendations in both periods, contrary to the consumption of meat, fish, and pulses. The consumption of energy and macronutrients was similar for all ages studied, with protein intake being slightly higher than the recommended values. Regarding micronutrients, practically the whole sample fell below the vitamin D requirements. In addition, the estimated daily intakes of vitamin $\mathrm{E}$ and iron, at 24 months, were below the recommended values for this population group. The mean intake of phenols was around $650 \mathrm{mg} /$ day. Flavanol intake as well as both types of fiber decreased from 18 to 24 months. In conclusion, although these results have to be confirmed in other populations, it seems pertinent to propose the design of nutritional strategies aimed at increasing the intake of vitamins D and $\mathrm{E}$ as well as iron in Spanish children up to 2 years.
\end{abstract}

Keywords: children; dietary pattern; nutrient intake; nutritional targets; vitamin D

\section{Introduction}

Adequate nutrition during early life is essential to ensure children's growth, health, and neurological development [1]. Scientific evidence substantiating the impact of early nutrition on the later development of non-communicable diseases, such as obesity, hypertension, and diabetes, is continuously growing [2,3]. Some studies have evidenced the impact of early feeding practice, such as breastfeeding duration and time of introduction of complementary food, on the risk of overweight and obesity [4,5]. Thus, the first 1000 days of life, beginning at conception and ending at 24 months, seem to represent the temporal window of opportunity for modulating the risk factors associated with the later development of these pathologies [2,6-8]. From birth to 6 months of age, the World Health Organization (WHO) recommends the use of exclusive breastfeeding to ensure the energy and nutrient requirements of the newborn [9]. However, from this moment, the complexity 
of the diet increases as different foods are progressively introduced into the infant diet, until a diet similar in composition to that of adults is achieved.

In Spain, most commonly, the introduction of new foods begins at around 6 months of age, so that by the age of 18 months, all the food groups have already been included in the infant diet [10]. Some authors have proposed that by the age of two, the tastes and food preferences that will condition the later diet and food preferences of the individual have already been determined [11]. Nonetheless, the dietary pattern and nutritional status of children receiving complementary feeding is still understudied [12-15]. The few epidemiological studies analyzing global diet quality in this population group have reported a high intake of protein in children's diet, in Spain and other European countries [16-19], which may act as obesogenic risk factor [17]. On the micronutrient level, iron and fiber were identified as two important nutritional targets for children up to 12 months of age [20]. Furthermore, a high intake of sodium, added sugars, and saturated fatty acids has also been reported in children [21,22]. Beyond the nutritional components, in the last few years, the intake of non-nutritive biologically active components, such as fibers and (poly)phenols, have attracted the interest of the scientific community. Although the direct health benefits of these compounds are not as extensively studied as in adults, a higher intake of dietary fiber has been associated with improved overall diet quality among children [23]. Moreover, higher intake (poly)phenols and flavonoids has been inversely associated with obesity [24]. On the basis of scientific evidence regarding the association between polyphenol consumption and the modulation of intestinal microbiota composition or in the regulation of peptides related to the regulation of solid food intake in the adult population, it is reasonable to expect that these may also be some of the mechanisms that explain the link with body weight in adolescents [24].

Therefore, the investigation of the dietary habits of children in this age range is of great importance for the establishment of early-life health promotion strategies that improve later health [25]. In this context, we aimed at describing the food intake, the nutritional status, and the consumption of bioactive compounds of children from the LAyDI cohort (Spain) at 18 and 24 months of age to explore differences among regions, gender, anthropometrical factors, and breast-feeding.

\section{Subjects and Methods}

This analysis is part of a prospective longitudinal study (LAyDI; Lactancia Materna y Desarrollo Infantil, "Breastfeeding and Child Development") including 1200 Spanish toddlers born between April 2017 and March 2018, visiting Primary Care Pediatricians from the PAPenREd research network. The initial sample was calculated from the 2015 census data published by the National Institute of Statistics [26] and selected at random by recruiting the first newborn to attend the consultation each month. Parents were informed of the objectives of the study and gave their written consent before enrollment. Ethical approval was obtained from the Ethics and Scientific Research Committee of the Principality of Asturias ( ${ }^{\circ}$ 213/16).

The subjects were recruited across different Spanish regions, as it is described in Supplementary Figure S1. The geographical aggregation was carried out at posteriori according to previous studies [27] in order to facilitate the interpretation of the results. The northern and central areas were the major contributors to the study sample ( $70 \%$ of the total).

Information concerning dietary assessment, medical status, and basal characteristics was obtained at 18 and 24 months in a sample of 426 children at 18 months of age (response rate of $42.14 \%$ ) and 336 at 24 months (response rate of $33.23 \%$ ).

\subsection{Nutritional Assessment}

Infant's dietary information was collected by means of a weekly and semi-quantitative food propensity questionnaire (FFQ) adapted from the pilot study for the Assessment of Nutrient Intake and Food Consumption Among Kids in Europe (PANCAKE) [28] for the 
Spanish population, thus including typical foods and traditional regional recipes. Furthermore, food diaries were designed through an online tool that included detailed dietary information grouped into 11 food groups according to European Prospective Investigation into Cancer (EPIC) classification (Supplementary Table S1) [29] and one extra group for processed infant food. The questionnaires were completed by children proxies who received it as an email. Detailed instructions for completing the food diary were included at the beginning of each food category and clarified by phone when necessary. The validated picture book developed by the PANCAKE consortium was used for portion size estimation according to EU-Menu recommendations. Special attention was paid to cooking practices, number and amount of ingredients used in each recipe, as well as questions concerning menu preparation (e.g., type of oil used, type of milk used), and other relevant information for the study, such as the consumption of skin-on fruit. Although the consumption of breast milk was recorded, it was not possible to quantify the volume ingested per feed, which implies an underestimation in the nutritional assessment of breastfed children. Food intake was converted into servings according to the infant portion sizes proposed by the Spanish "General Direction of Public Health and Consumption" in order to compare the adherence to dietary recommendations [30]. Moreover, the consumption of foods was transformed into energy and macro- and micronutrients using the food composition tables developed by the Centro de Enseñanza Superior de Nutrición Humana y Dietética (CESNID) [31]. Additionally, detailed information regarding the type of protein, lipid, or carbohydrate consumed was completed from the food composition tables published by the United States Department of Agriculture (USDA) [32]. The content of the major classes and subclasses of (poly)phenol in the foods consumed in the sample was calculated using the Phenol-Explorer database [33]. This tool contains detailed information of the polyphenol content in more than 400 European foods, mainly determined by highperformance liquid chromatography (HPLC), gas chromatography (GC), and capillary electrophoresis (CE) [33]. The major classes of fiber (soluble and insoluble types) were completed from Marlett et al. [34], and nutritional composition data of infant formula, cereal products, and complementary foods (mixed puree or snacks and desserts) were adapted from Gómez-Martín et al. [35].

\subsection{Anthropometric Measures}

Child height and weight were recorded to the nearest $0.1 \mathrm{~cm}$ and $0.1 \mathrm{~kg}$, respectively, by pediatric nurses at the age of 18 and 24 months. Body mass index (BMI) was calculated as weight in kilograms divided by the square of height in meters and adjusted by child age and gender. BMI z-score was calculated relative to WHO Child Growth Standards [36] using the WHO ANTHRO Software for Calculating Anthropometry, Version 2.0 [37].

\subsection{Statistical Analyses}

Statistical analysis was performed using IBM SPSS 24.0 (IBM SPSS, Inc., Chicago, IL, USA). Goodness of fit to the normal distribution was checked by means of the KolmogorovSmirnov test. Overall, categorical variables were summarized as percentages, and continuous variables using means and standard deviations. Chi-square test and independent samples Student $t$-test were used for intragroup comparisons and Bonferroni multiple comparison. Differences in general characteristics and food and nutrient intake were analyzed according to the geographical location of participants and age group. GraphPad Prism 8 and Biorender were used for graphical representations. Adherence to Dietary Reference Values (DRVs) was calculated using the European Food Safety Authority (EFSA) recommendations for children aged $1-3$ years $[38,39]$. Specifically, the parameters used were average requirement (AR), adequate intake (AI), and reference intake range (RI) for 1-3-year-olds. AR was determined for calcium, iron, zinc, folate, niacin, riboflavin, thiamine, vitamin $\mathrm{A}$, vitamin $\mathrm{B}_{6}$, and vitamin $\mathrm{C}$, while $\mathrm{AI}$ was determined for phosphorus, magnesium, manganese, vitamin $B_{12}$, vitamin $\mathrm{E}$, and vitamin $\mathrm{D}$. The $\mathrm{AI}$ can also be used to determine the proportion of individuals with adequate nutrient intake. 


\section{Results}

\subsection{Description of the Sample}

The general characteristics of the study sample according to age are listed in Table 1. The gender-balanced samples consisted of a total of 426 and 336 subjects, at 18 and 24 months of age, respectively. Almost the whole sample had received the prescribed vaccinations from birth to 18 months of age, did not report health problems in the 6 months prior to the interview, and slept between 11 and $14 \mathrm{~h}$ /day. Regarding dietary habits, despite most of the volunteers following a normal diet at 18 and 24 months, significant variations in its texture were observed across ages. The percentage of children consuming a semi-solid diet decreased from $45.2 \%$ at 18 months to $28 \%$ at 24 months of age. In addition, our data reveal that over $30 \%$ of the children were still breastfeeding. Concerning anthropometric parameters, the percentage of children with normal weight (BMI z-score from -1 to 1 ) decreased significantly from 18 to 24 months (70.9 to $63.7 \%)$.

Table 1. General characteristics of the LAyDI cohort by age.

\begin{tabular}{|c|c|c|c|}
\hline \multicolumn{2}{|c|}{ Characteristics } & \multirow{2}{*}{$\begin{array}{l}18 \text { Months } \\
\text { (N 426) }\end{array}$} & \multirow{2}{*}{$\begin{array}{c}24 \text { Months } \\
\text { (N 336) }\end{array}$} \\
\hline Gender & Boys & & \\
\hline & Girls & $213(50)$ & $166(49.4)$ \\
\hline Health status $^{1}$ & & & \\
\hline Complete immunization & Yes & $422(99.3)$ & - \\
\hline Illness in the last 6 months & No & 415 (97.6) & - \\
\hline \multirow[t]{4}{*}{ Sleep duration (hours/day) } & $<11$ & $46(10.8)$ & - \\
\hline & $11-14$ & $337(79.3)$ & - \\
\hline & $14-16$ & $41(9.6)$ & - \\
\hline & $>16$ & $1(0.2)$ & - \\
\hline \multicolumn{4}{|l|}{ Diet } \\
\hline Special diet 2,3 & Yes & $29(6.9)$ & $12(3.6) *$ \\
\hline \multirow[t]{3}{*}{ Diet consistency $^{1}$} & Mashed foods & $3(0.7)$ & $1(0.3)$ \\
\hline & Semi-solid & $192(45.2)$ & $94(28) *$ \\
\hline & Regular & $230(54.1)$ & $241(71.7) *$ \\
\hline Breastfeeding ${ }^{1}$ & Yes & $141(33.2)$ & $95(28.4)$ \\
\hline \multicolumn{4}{|l|}{ Anthropometric data } \\
\hline Weight $(\mathrm{kg})^{1,4}$ & & $10.9 \pm 1.2$ & $12.3 \pm 1.6^{*}$ \\
\hline Height $(\mathrm{cm})^{1,3}$ & & $81.6 \pm 3.2$ & $86.9 \pm 4.8^{*}$ \\
\hline \multirow[t]{4}{*}{ BMI z-score ${ }^{1,4}$} & Underweight $(-5.0$ to $<-1)$ & $54(12.7)$ & $52(16.1)$ \\
\hline & Normal weight ( -1 to 1$)$ & $302(70.9)$ & $214(63.7)$ * \\
\hline & Overweight (>1 to 2$)$ & $57(13.4)$ & $54(16.1)$ \\
\hline & Obese $(>2)$ & $12(2.8)$ & $14(4.2)$ \\
\hline
\end{tabular}

Data are presented as mean \pm standard deviation or $\mathrm{n}(\%) .{ }^{1} \mathrm{~N} 425,{ }^{2} \mathrm{~N} 423$ at 18 months and ${ }^{3} \mathrm{~N} 335,{ }^{4} \mathrm{~N} 334$ at 24 months. ${ }^{*} p$ value for difference between 18 and 24 months from $t$-test for continuous variables and from chi-square test for categorical variables.

\subsection{Dietary Intake and Related Factors}

The intake of the major food groups was described in the sample and analyzed according to gender, region, breastfeeding, and BMI z-score ranges at 18 and 24 months (Table 2). The obtained results point to the absence of differences in food consumption for both ages by gender and region; hereafter, the analyses were conducted for the whole sample. The only differences observed by region were a higher intake of vegetables and lower intake of meat and fish in the south and the Balearic islands, respectively, at 18 months, and differences in the consumption of eggs and fruits at 24 months on the Balearic islands and in southern Spain. Concerning breastfeeding, children receiving breast milk reported a lower intake of sweets and a higher intake of eggs at 18 months and a lower intake of potatoes, meat, and fish at 24 months, compared to those who were not breastfed. As expected, dairy product consumption, excluding breast milk, was higher in non-breastfeeding groups independent of age (Table 2, (A,B)). During the period of study, the consumption of fruits, vegetables, potato and tubers, and processed infant products decreased, and the consumption of meat and meat products, eggs, cereals and cereal products, and sweets and desserts increased (Table 2, (A,B)). 
Table 2. Major food intake in the LAyDI cohort according to gender, region, breastfeeding (BF), and body mass index (BMI) at 18 (A) and 24 months (B).

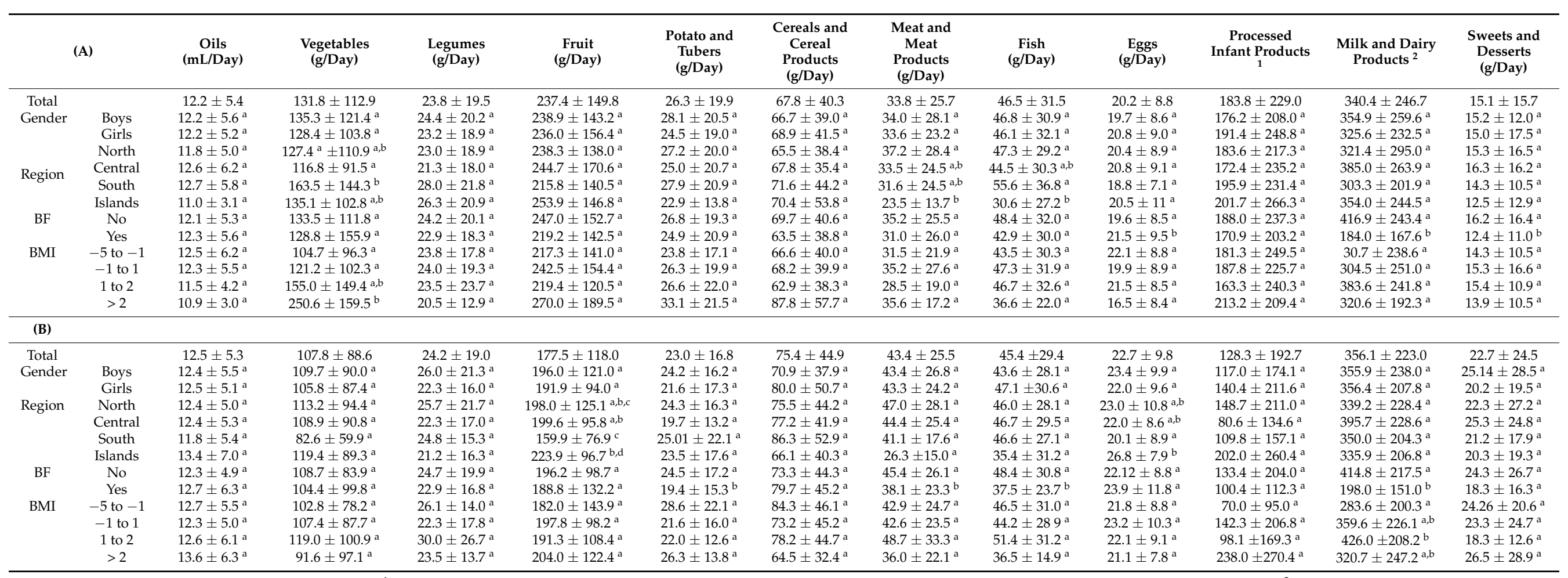

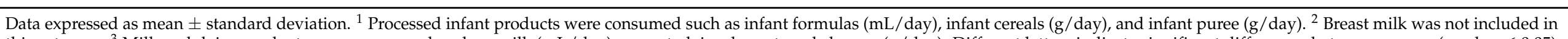

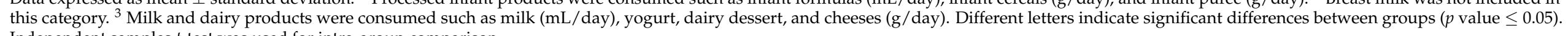
Independent samples $t$-test was used for intra-group comparison. 
In order to evaluate the proportionality of the diet consumed, the average serving of the major food groups at 18 and 24 months was compared with the available recommendations for the infant population. The presence of vegetables, fruits, dairy, and eggs in the children's diet was lower than recommendations, contrary to the consumption of meat, fish, and pulses in both periods (Figure 1).
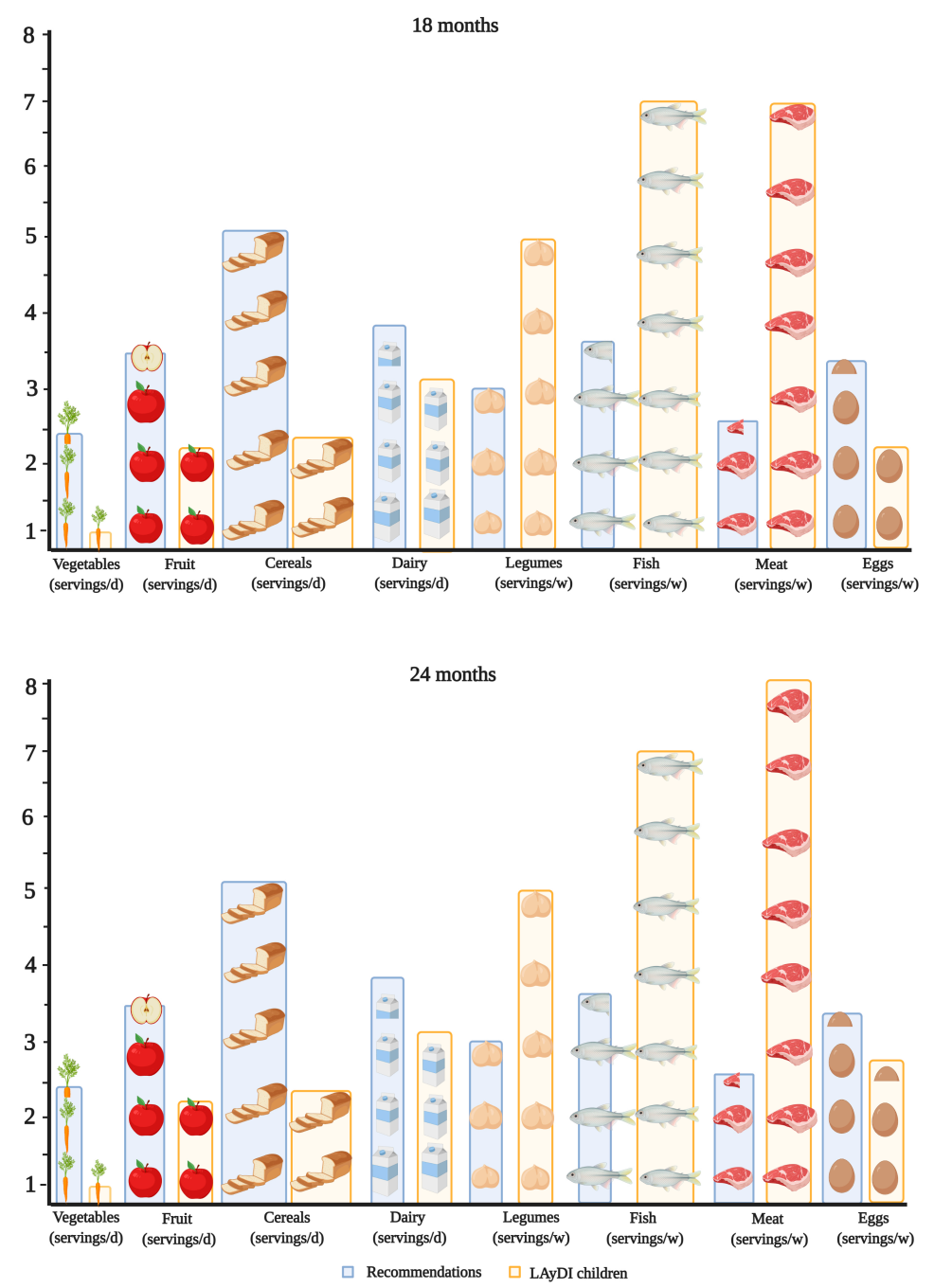

Figure 1. Adherence to dietary recommendations in the sample. D, day. W, week.

\subsection{Nutritional Targets in Children}

A detailed description of the infant's nutritional status, as well as a comparison with the recommended daily values by age is presented in Table 3. No significant differences by age were observed for energy or macronutrients. Nevertheless, it was revealed that at 24 months of age, fiber intake was lower than at 18 months, whereas the intake of monounsaturated fatty acids was higher. A moderate excess in protein intake was observed in both groups (Figure 2). Regarding micronutrients, the intake of magnesium, iron, and vitamin E were lower than the recommended values in the $P_{25}$ of the sample at 18 and 24 months. It is remarkable that the whole sample is under the recommended intake of vitamin D at 18 and 24 months. 
Table 3. Energy and macro- and micronutrient intake from diet compared with Dietary Reference Values (DRV) in the LAyDI cohort by age.

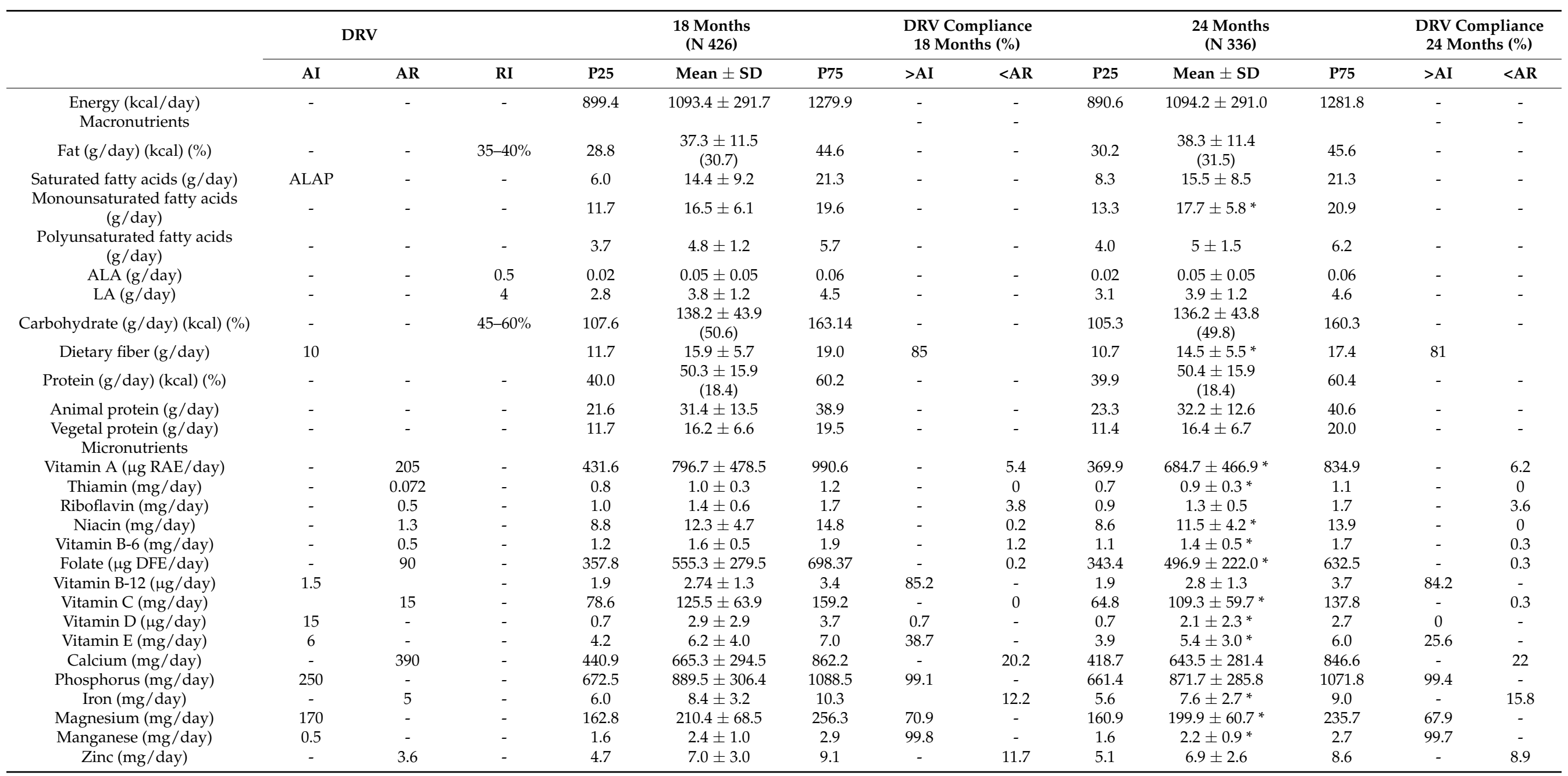

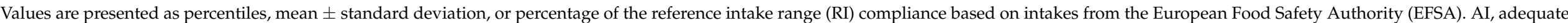
intake. ALA, alpha-linolenic acid. ALAP, as low as possible. AR, average requirement. LA, linoleic acid. RI, reference intake range. * $p$ value for difference between 18 and 24 months from $t$-test. 


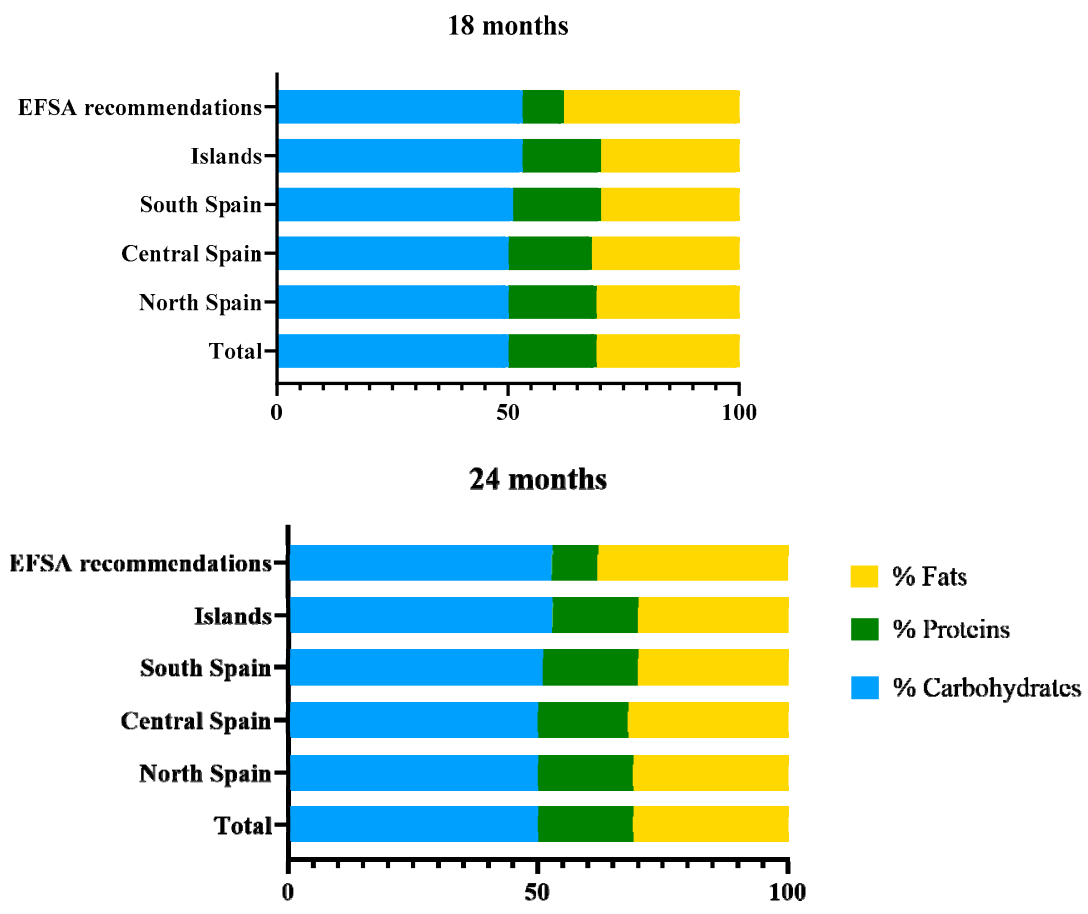

Figure 2. Percentage of the total energy intake provided by each macronutrient in the sample by region at 18 and 24 months. Mean daily energy intake at 18 months: total sample 1093.4 kcal; north Spain $1067.8 \mathrm{kcal}$; central Spain $1122.6 \mathrm{kcal}$; south Spain $1122.2 \mathrm{kcal}$; the islands $1053.9 \mathrm{kcal}$. Mean daily energy intake at 24 months: total sample $1094.2 \mathrm{kcal}$; north Spain $1093.30 \mathrm{kcal}$; central Spain $1117.6 \mathrm{kcal}$; south Spain $1083.2 \mathrm{kcal}$; the islands $1064.7 \mathrm{kcal}$.

\subsection{Bioactive Compounds}

The average intake of the major classes and subclasses of (poly)phenols and fiber is presented in Table 4. Total phenols intake in the sample was $659.4 \mathrm{mg} /$ day at 18 months and $654.2 \mathrm{mg} /$ day at 24 months, with flavonoids and phenolic acids being the best contributors to their intake independent of age (data not shown). The intake of flavonols, total fiber, and insoluble and soluble fiber decreased with age.

Table 4. Differences in bioactive compound intakes according to age in the LAyDI cohort.

\begin{tabular}{|c|c|c|c|c|c|c|}
\hline \multirow[b]{2}{*}{ Bioactive Compounds } & \multicolumn{3}{|c|}{18 Months } & \multicolumn{3}{|c|}{24 Months } \\
\hline & Mean \pm SD & $\mathbf{P} 25$ & P75 & Mean \pm SD & P25 & P75 \\
\hline Total phenols (mg/day) & $659.4 \pm 335.0$ & 436.4 & 830.0 & $654.2 \pm 322.5$ & 432.0 & 842.8 \\
\hline Total (poly)phenols (mg/day) ${ }^{1}$ & $153.7 \pm 84.1$ & 97.3 & 195.4 & $151.0 \pm 81.7$ & 97.6 & 188.2 \\
\hline Flavonoids (mg/day) & $109.2 \pm 67.2$ & 62.3 & 142.3 & $104.9 \pm 61.4$ & 63.4 & 134.3 \\
\hline Anthocyanins & $23.9 \pm 23.1$ & 8.6 & 29.5 & $25.3 \pm 28.6$ & 6.7 & 3.7 \\
\hline Dihydrochalcones & $1.7 \pm 1.0$ & 1.1 & 1.7 & $1.8 \pm 1.0$ & 1.1 & 2.2 \\
\hline Flavanols & $42.2 \pm 31.9$ & 17.3 & 55.9 & $42.8 \pm 31.0$ & 20.7 & 56.5 \\
\hline Flavanones & $27.9 \pm 25.3$ & 6.8 & 38.3 & $27.8 \pm 25.4$ & 4.0 & 41.7 \\
\hline Flavones & $0.6 \pm 0.8$ & 0.2 & 0.7 & $0.5 \pm 0.8$ & 0.1 & 0.5 \\
\hline Flavonols & $19.0 \pm 26.8$ & 7.1 & 20.3 & $14.0 \pm 11.0 *$ & 7.2 & 17.8 \\
\hline Isoflavanoids & $0.7 \pm 2$ & 0.08 & 0.6 & $0.8 \pm 2.9$ & 0.1 & 0.6 \\
\hline Phenolic acids (mg/day) & $40.9 \pm 21.9$ & 26.2 & 53.5 & $42.0 \pm 23.0$ & 25.8 & 53.7 \\
\hline Lignans (mg/day) & $0.1 \pm 0.2$ & 0.02 & 0.3 & $0.1 \pm 0.2$ & 0.02 & 0.3 \\
\hline Non-phenolic metabolites (mg/day) & $1.7 \pm 0.7$ & 1.2 & 2.1 & $1.8 \pm 0.7$ & 1.3 & 2.3 \\
\hline Other polyphenols (mg/day) & $4.3 \pm 2.5$ & 3.3 & 4.9 & $4.8 \pm 2.8$ & 3.3 & 6.8 \\
\hline Dietary fiber (g/day) & $15.7 \pm 5.7$ & 11.7 & 19.0 & $14.5 \pm 5.5 *$ & 10.7 & 17.4 \\
\hline Insoluble & $10.4 \pm 4.3$ & 7.4 & 12.7 & $9.3 \pm 4.03 *$ & 6.4 & 11.5 \\
\hline Soluble & $2.1 \pm 1.0$ & 1.5 & 2.5 & $1.9 \pm 0.9 *$ & 1.3 & 2.2 \\
\hline
\end{tabular}

Values are presented as mean \pm standard deviation and percentiles. ${ }^{1}$ Total (poly)phenols were calculated as the sum of total flavonoids, phenolic acid, lignans, non-phenolic metabolites, and other polyphenols. ${ }^{*} p$ value for difference between 18 and 24 months from $t$-test. 


\section{Discussion}

This study represents the first approach describing the dietary intake and nutritional status associated with complementary feeding in a representative sample of 18- and 24-month-old children from a Mediterranean country. Considering the health impact that nutritional habits at this life-stage may have, the knowledge gained from these results may be useful in the design of future strategies focused on the prevention of non-communicable diseases for the pediatric age group.

As expected, from the age of 18 months, all food groups were present in the toddlers' diets. However, in contrast to what has been published on the adult population, no significant differences in food consumption were observed according to regions or gender at any age. In accordance with previous data in the literature, describing a nutrient-poor diet in children who are breastfed for a short time [40,41], a higher consumption of sweets in non-breastfed children at 18 months was observed. Surprisingly, a positive association was found between BMI z-score and vegetable consumption. Vegetables at this age are the basis of feeding and are also used as an accompaniment to the rest of the food groups. Thus, it is probable that this result reflects the consumption of a larger portion size in an indirect way.

It is noteworthy that the percentage of children that consumed vegetables (data not shown), fruits, and infant cereals was slightly higher than that observed in other studies of the same age group [42,43]. Interestingly, with the transition to 24 months, a reduction in the intake of fruits and vegetables (the major fiber sources in the sample) was observed in favor of meat and meat products, which is closer to the adult diet characteristic of westernized countries. On the basis of the estimated portion sizes for the 2-year-old pediatric population, the children in the sample had a clear excess of almost all high-protein foods, such as meat and meat products, fish and seafood, and legumes. In contrast, vegetables, fruits, and dairy products were less present in the diet than indicated. Although egg consumption was below the recommended frequency, it may have been underestimated, since egg is often used as an ingredient in the preparation of other products and, therefore, is difficult to record through an FFQ.

In consequence, the contribution of macronutrients to total energy intake was similar to previous studies, showing a moderate increase in protein (18\% at both ages) and lipids (31\% at 18 months and $32 \%$ at 24 months) as compared to the recommended values (Figure 2) [44-47]. This profile probably represents the characteristic energy distribution of adults in westernized countries [48]. Some of the differences observed with respect to other studies in children, such as ALSALMA [19] and DONALD [49], may be due to several factors including (i) the different methodology for dietary assessment; (ii) the wide age ranges compared, as few studies strictly adhere to 18 months; (iii) the variations in dietary habits among the studied populations. Our sample showed a lower intake of total and saturated fatty acids ( 37.3 and $14.4 \mathrm{~g} /$ day at 18 months and 38.3 and $15.5 \mathrm{~g} /$ day at 24 months) and a higher intake of monounsaturated fatty acids (16.5 g/day at 18 and $17.7 \mathrm{~g} /$ day at 24 months), compared to other studies carried out in non-Mediterranean countries [50-52], which is consistent with the use of olive oil as the main culinary fat in our population [53].

To elaborate, certain micronutrients, such as folate, vitamin D, iron, and calcium, have a key role during early life [8]. Regarding vitamins, folate intake in our study was higher than that shown in Norwegian toddlers at 24 months of age [54] and in the US Feeding Infants and Toddlers Study (FITS) between 12 and 24 months of age (555.3 and $496.9 \mu \mathrm{g} /$ day vs. 87 and $308 \mu \mathrm{g} /$ day, respectively) [55]. This increase in the average intake in our sample may be of interest because of the role of folic acid in the nervous system and blood-forming organs [56]. One of the most striking results in this work is the low intake of vitamin $\mathrm{D}$ in the sample. Despite calcium intake in the $\mathrm{P}_{25}$ being slightly above the recommended value (440.9 and $418.7 \mathrm{mg}$ /day), vitamin D improves its intestinal absorption, promoting the mineralization of the bone matrix [57]. The determination of vitamin $\mathrm{D}$ intake is dependent on the information collected in food composition tables and is subject to wide seasonal variation. The intake of this vitamin is consistently low throughout the 
literature [58-60]; therefore, it seems reasonable to propose it as a target for intervention in this population group. For this purpose, in order to define vitamin D deficiency accurately, the serum determination of $25(\mathrm{OH})$ vitamin $\mathrm{D}$ and the recording of information relating to the child's skin color, frequency of sun exposure, and supplementation would be advisable. Furthermore, since $30 \%$ of children are below the AI of $\mathrm{Mg}$ at 24 months, the levels of this mineral, which plays an essential role in bone metabolism, should be monitored together with calcium and vitamin D.

As regards minerals, iron intake is essential for the maintenance of the energy of the neural cells and the homeostasis of the neurotransmitters [8,61]. In accordance with various existing studies that reveal a low intake of this mineral $[59,62]$, the average intake in the $\mathrm{P}_{25}$ of the sample was slightly lower than EFSA recommendations. This may be explained by the fact that the intake of processed baby foods, usually fortified with iron, decreased from 18-24 months.

To our knowledge, this is the first study describing the intake of bioactive compounds in the Spanish infant population. Although there are only a few publications with which these results can be compared, (poly)phenol intake was slightly higher than in other European cohorts [63] and similar to that reported in children from other Mediterranean populations, both in the average amount consumed [64] and in the contribution of the individual classes to the total intake $[65,66]$. In both age groups, the main dietary source of anthocyanins was strawberries, flavanols were provided by apples, bananas, pears, and lentils, and flavanones were derived mainly from oranges (data not shown). This is to be expected, since foods such as coffee, tea, and alcoholic beverages, which represent a significant portion of the polyphenol intake in the adult population, are not consumed in this age range. Different surveys in developed countries have identified fiber as one of the dietary components whose intake should be increased in the adult population. The results presented in this study address a gap in the literature as regards the intake of fiber in children under 2 years old, including the different types of fiber consumed, which can be related to different physiological effects. In this sense, the daily dietary fiber in our sample oscillates around $15 \mathrm{~g} /$ day, which is superior to what is reported in the majority of the literature $[19,55,67]$ and can be adapted to the values recommended by the EFSA for this compound [68].

The study has some limitations inherent to its observational nature and the collection of dietary information. When interpreting this information, it should be considered that the energy and nutrient content of processed baby foods was considered, a factor that has been underestimated in the literature so far. Moreover, the Phenol-Explorer database used in the present study allowed us to provide information on (poly)phenol intake with a level of detail that had not been achieved before in Spanish children. However, at the time of analyzing the intake of bioactive compounds, it was not possible to incorporate the content of processed baby foods, since information concerning the type of fiber or (poly)phenol content was not present on the product label. Furthermore, we were not able to evaluate (poly)phenols from spices, even though these are a good dietary source of these compounds, since these data had not been collected in the FFQ. Although the quality of the FFQ depends on the memory of the respondent, its ability to accurately classify energy and all nutrient intakes in infants is enhanced by the quality and detail of the information collected [69]. The use of the methodology and questionnaires developed by PANCAKE allows for comparison with other studies on the European child population.

\section{Conclusions}

This work addresses certain gaps in the knowledge concerning infant nutrition and provides key information for the design of health promoting strategies for toddlers. Our results allowed us to affirm that the introduction of complementary feeding is similar throughout the Spanish national territory and is, in general, adequate in terms of the variables studied. It seems advisable to monitor protein consumption and to promote the maintenance of breastfeeding until 18 months of age, because of its association with a lower 
consumption of certain foods related to the risk of child obesity and related pathologies. Finally, studies specifically designed to analyze vitamin D deficiency in children and its impact on bone mineral balance would be of great interest.

Supplementary Materials: The following are available online at https:/ / www.mdpi.com/1660-460 1/18/3/939/s1, Figure S1: Geographical distribution of the sample, Table S1: Food group description.

Author Contributions: All authors wrote sections of the first draft and thoroughly edited the manuscript. All authors have read and agreed to the published version of the manuscript.

Funding: This work was financed by PCIN-2015-233 (Project EarlyMicroHealth from the EU Joint Program Initiative HDHL) (MINECO/FEDER, UE) and by the University of Oviedo (Diet, Rhythms and Early Acquisition Microbiota (DREAMS) Project, REF. 2017/00001/003/005/013). María GómezMartín is the recipient of a predoctoral FPU contract (FPU18/03393) funded by the Spanish Ministry of 302 Science, Innovation and Universities.

Institutional Review Board Statement: The study was conducted according to the guidelines of the Declaration of Helsinki and approved by Ethics and Scientific Research Committee of the Principality of Asturias ( $n^{\circ}$ 213/16).

Informed Consent Statement: Informed consent was obtained from all subjects involved in the study.

Data Availability Statement: Not applicable.

Acknowledgments: The authors thank Primary Care Pediatrics Research Network of the Spanish Association of Primary Care Pediatrics (AEPap). https://www.aepap.org/sites/default/files/noticia/ archivos-adjuntos/listado_pediatras_colaboradores_-_estudio_laydi.pdf

Conflicts of Interest: The authors declare no conflict of interest.

\section{References}

1. Emmett, P.M.; Jones, L.R. Diet, growth, and obesity development throughout childhood in the Avon Longitudinal Study of Parents and Children. Nutr. Rev. 2015, 73, 175-206. [CrossRef] [PubMed]

2. Mameli, C.; Mazzantini, S.; Zuccotti, G. Nutrition in the First 1000 Days: The origin of childhood obesity. Int. J. Environ. Res. Public Health 2016, 13, 838. [CrossRef] [PubMed]

3. Schwarzenberg, S.J.; Georgieff, M.K. Advocacy for improving nutrition in the first 1000 days to support childhood development and Adult Health. Pediatrics 2018, 141, e20173716. [CrossRef]

4. Schack-Nielsen, L.; Sørensen, T.I.; Mortensen, E.L.; Michaelsen, K.F. Late introduction of complementary feeding, rather than duration of breastfeeding, may protect against adult overweight. Am. J. Clin. Nutr. 2010, 91, 619-627. [CrossRef] [PubMed]

5. Weng, S.F.; Redsell, S.A.; Swift, J.A.; Yang, M.; Glazebrook, C.P. Systematic review and meta-analyses of risk factors for childhood overweight identifiable during infancy. Arch. Dis. Child. 2012, 97, 1019-1026. [CrossRef]

6. Taveras, E.M. Childhood obesity risk and prevention: Shining a lens on the first 1000 days. Child. Obes. 2016, 12, $159-161$. [CrossRef]

7. Woo Baidal, J.A.; Locks, L.M.; Cheng, E.R.; Blake-Lamb, T.L.; Perkins, M.E.; Taveras, E.M. Risk factors for childhood cbesity in the first 1,000 days. Am. J. Prev. Med. 2016, 50, 761-779. [CrossRef]

8. Beluska-Turkan, K.; Korczak, R.; Hartell, B.; Moskal, K.; Maukonen, J.; Alexander, D.E.; Salem, N.; Harkness, L.; Ayad, W.; Szaro, J.; et al. Nutritional gaps and supplementation in the first 1000 days. Nutrients 2019, 11, 2891. [CrossRef]

9. World Health Organisation (WHO). Appropriate Complementary Feeding. Available online: https://www.who.int/elena/titles/ complementary_feeding/en/ (accessed on 6 December 2020).

10. Lázaro, A. Alimentación del lactante sano. Hosp. Tarrasa Hosp. Clínica Zaragoza 2011, I, 287-295. [CrossRef]

11. Nicklaus, S.; Boggio, V.; Chabanet, C.; Issanchou, S. A prospective study of food variety seeking in childhood, adolescence and early adult life. Appetite 2005, 44, 289-297. [CrossRef]

12. Brisbois, T.D.; Farmer, A.P.; McCargar, L.J. Early markers of adult obesity: A review. Obes. Rev. 2012, 13, 347-367. [CrossRef] [PubMed]

13. Livingstone, M.B.E.; Robson, P.J.; Wallace, J.M.W. Issues in dietary intake assessment of children and adolescents. Br. J. Nutr. 2004, 92, S213-S222. [CrossRef] [PubMed]

14. Livingstone, M.B.E.; Robson, P.J. Measurement of dietary intake in children. Proc. Nutr. Soc. 2000, 59, 279-293. [CrossRef] [PubMed]

15. Ortiz-Andrellucchi, A.; Henríquez-Sánchez, P.; Sánchez-Villegas, A.; Peña-Quintana, L.; Mendez, M.; Serra-Majem, L. Dietary assessment methods for micronutrient intake in infants, children and adolescents: A systematic review. Br. J. Nutr. 2009, 102, S87-S117. [CrossRef] 
16. Ruiz, E.; Ávila, J.; Valero, T.; del Pozo, S.; Rodriguez, P.; Aranceta-Bartrina, J.; Gil, Á.; González-Gross, M.; Ortega, R.; Serra-Majem, L.; et al. Macronutrient Distribution and Dietary Sources in the Spanish Population: Findings from the ANIBES Study. Nutrients 2016, 8, 177. [CrossRef]

17. Hörnell, A.; Lagström, H.; Lande, B.; Thorsdottir, I. Protein intake from 0 to 18 years of age and its relation to health: A systematic literature review for the 5th Nordic Nutrition Recommendations. Food Nutr. Res. 2013, 57, 21083. [CrossRef]

18. Madrigal, C.; Soto-Méndez, M.J.; Hernández-Ruiz, Á.; Valero, T.; Ávila, J.M.; Ruiz, E.; Lara Villoslada, F.; Leis, R.; Martínez de Victoria, E.; Moreno, J.M.; et al. Energy intake, macronutrient profile and food sources of spanish children aged one to $<10$ years-results from the EsNuPI Study. Nutrients 2020, 12, 893. [CrossRef]

19. Dalmau, J.; Moráis, A.; Martínez, V.; Peña-Quintana, L.; Varea, V.; Martínez, M.J.; Soler, B. Evaluación de la alimentación y consumo de nutrientes en menores de 3 años. Estudio piloto ALSALMA. An. Pediatr. 2014, 81, 22-31. [CrossRef]

20. Zuccotti, G.; Cassatella, C.; Morelli, A.; Cucugliato, M.; Catinello, G.; del Balzo, V.; Guidarelli, L.; Agostoni, C.; Mameli, C.; Troiano, E.; et al. Nutrient intake in Italian infants and toddlers from north and south Italy: The Nutrintake 636 Study. Nutrients 2014, 6, 3169-3186. [CrossRef]

21. Demmer, E.; Cifelli, C.; Houchins, J.; Fulgoni, V. The Pattern of Complementary Foods in American Infants and Children Aged 0-5 Years Old-A Cross-Sectional Analysis of Data from the NHANES 2011-2014. Nutrients 2018, 10, 827. [CrossRef]

22. Huysentruyt, K.; Laire, D.; Van Avondt, T.; De Schepper, J.; Vandenplas, Y. Energy and macronutrient intakes and adherence to dietary guidelines of infants and toddlers in Belgium. Eur. J. Nutr. 2016, 55, 1595-1604. [CrossRef] [PubMed]

23. Finn, K.; Jacquier, E.; Kineman, B.; Storm, H.; Carvalho, R. Nutrient intakes and sources of fiber among children with low and high dietary fiber intake: The 2016 feeding infants and toddlers study (FITS), a cross-sectional survey. BMC Pediatr. 2019, 19, 446. [CrossRef] [PubMed]

24. Wisnuwardani, R.W.; De Henauw, S.; Forsner, M.; Gottrand, F.; Huybrechts, I.; Knaze, V.; Kersting, M.; Le Donne, C.; Manios, Y.; Marcos, A.; et al. Polyphenol intake and metabolic syndrome risk in European adolescents: The HELENA study. Eur. J. Nutr. 2020, 59, 801-812. [CrossRef] [PubMed]

25. Scaglioni, S.; De Cosmi, V.; Ciappolino, V.; Parazzini, F.; Brambilla, P.; Agostoni, C. Factors influencing children's eating behaviours. Nutrients 2018, 10, 706. [CrossRef]

26. Instituto Nacional de Estadística. Movimiento Natural de la Población; Instituto Nacional de Estadística: Madrid, Spain, 2015; Volume 303, pp. 1-12. Available online: www.ine.es (accessed on 6 December 2020).

27. González, C.A.; Argilaga, S.; Agudo, A.; Amiano, P.; Barricarte, A.; Beguiristain, J.M.; Chirlaque, M.D.; Dorronsoro, M.; Martinez, C.; Navarro, C.; et al. Diferencias sociodemográficas en la adhesión al patrón de dieta mediterránea en poblaciones de España. Gac. Sanit. 2002, 16, 214-221. [CrossRef]

28. Ocké, M.; de Boer, E.; Brants, H.; van der Laan, J.; Niekerk, M.; van Rossum, C.; Temme, L.; Freisling, H.; Nicolas, G.; Casagrande, C.; et al. PANCAKE-Pilot study for the assessment of nutrient intake and food consumption among kids in Europe. EFSA Support. Publ. 2012, 9. [CrossRef]

29. Slimani, N.; Fahey, M.; Welch, A.; Wirfält, E.; Stripp, C.; Bergström, E.; Linseisen, J.; Schulze, M.; Bamia, C.; Chloptsios, Y.; et al. Diversity of dietary patterns observed in the European Prospective Investigation into Cancer and Nutrition (EPIC) project. Public Health Nutr. 2002, 5, 1311-1328. [CrossRef]

30. Dirección General de Salud Púlbica y Consumo. La Alimentación de 1 a 3 años, 4th ed.; Dirección General de Salud Púlbica y Consumo: La Rioja, Spain, 2019; pp. 1-20.

31. Centro de Ensenanza Superior de Nutricion Humana y Dietetica (CESNID). Tablas de Composicion de Alimentos por Medidas Caseras de Consumo Habitual en España; McGrawHill, Ed.; Publicaciones y Ediciones de la Universidad de Barcelona: Barcelona, Spain, 2008.

32. U.S. Department of Agriculture Agricultural Research Service. FoodData Central. Available online: www.fdc.nal.usda.gov (accessed on 6 December 2020).

33. Neveu, V.; Perez-Jimenez, J.; Vos, F.; Crespy, V.; du Chaffaut, L.; Mennen, L.; Knox, C.; Eisner, R.; Cruz, J.; Wishart, D.; et al. Phenol-Explorer: An online comprehensive database on polyphenol contents in foods. Database 2010, 2010, bap024. [CrossRef]

34. Marlett, J.A.; Cheung, T.F. Database and quick methods of assessing typical dietary fiber intakes using data for 228 commonly consumed foods. J. Am. Diet. Assoc. 1997, 97, 1139-1151. [CrossRef]

35. Gómez-Martín, M.; Arboleya, S.; Gueimonde, M.; González, S. Nutritional composition of processed baby foods targeted at infants from 0-12 months. J. Food Compos. Anal. 2019, 79, 55-62. [CrossRef]

36. World Health Organisation (WHO). WHO child growth standards. Rev. Chil. Pediatría 2009, 80. [CrossRef]

37. World Health Organisation (WHO). WHO Anthro for Personal Computers 2010. Available online: http://www.who.int/ childgrowth/software/en/ (accessed on 6 December 2020).

38. European Food Safety Authority (EFSA) Panel on dietetic products nutrition and allergies (NDA) overview on Dietary Reference Values for the EU population as derived by the EFSA Panel on Dietetic Products, Nutrition and Allergies (NDA). EFSA J. 2017, 4, $1-15$.

39. Children, A.C.; Male, G.; Ai, F.; Na, N.A.; Na, P.; Ri, N.A.; Na, N.A.; Na, U.L.; Ar, N.A.; Children, A.C.; et al. Scientific Opinion on Dietary Reference Values for energy. EFSA J. 2013, 11, 1-7. [CrossRef] 
40. Bell, L.K.; Jansen, E.; Mallan, K.; Magarey, A.M.; Daniels, L. Poor dietary patterns at 1-5 years of age are related to food neophobia and breastfeeding duration but not age of introduction to solids in a relatively advantaged sample. Eat. Behav. 2018, 31, 28-34. [CrossRef] [PubMed]

41. Husk, J.S.; Keim, S.A. Breastfeeding and dietary variety among preterm children aged 1-3 years. Appetite 2016, 99, 130-137. [CrossRef]

42. Siega-Riz, A.M.; Deming, D.M.; Reidy, K.C.; Fox, M.K.; Condon, E.; Briefel, R.R. Food consumption patterns of infants and toddlers: Where are we now? J. Am. Diet. Assoc. 2010, 110, S38-S51. [CrossRef]

43. Yu, P.; Denney, L.; Zheng, Y.; Vinyes-Parés, G.; Reidy, K.C.; Eldridge, A.L.; Wang, P.; Zhang, Y. Food groups consumed by infants and toddlers in urban areas of China. Food Nutr. Res. 2016, 60, 30289. [CrossRef]

44. Kyttälä, P.; Erkkola, M.; Kronberg-Kippilä, C.; Tapanainen, H.; Veijola, R.; Simell, O.; Knip, M.; Virtanen, S.M. Food consumption and nutrient intake in Finnish 1-6-year-old children. Public Health Nutr. 2010, 13, 947-956. [CrossRef]

45. Manios, Y.; Grammatikaki, E.; Papoutsou, S.; Liarigkovinos, T.; Kondaki, K.; Moschonis, G. Nutrient Intakes of Toddlers and Preschoolers in Greece: The GENESIS Study. J. Am. Diet. Assoc. 2008, 108, 357-361. [CrossRef]

46. Zheng, M.; Campbell, K.J.; Scanlan, E.; McNaughton, S.A. Development and evaluation of a food frequency questionnaire for use among young children. PLoS ONE 2020, 15, e0230669. [CrossRef]

47. Lim, H.X.; Toh, J.Y.; Tan, K.H.; Chong, Y.-S.; Yap, F.; Godfrey, K.M.; Lee, Y.S.; Chong, M.F.-F. Validation of a semi-quantitative FFQ for 18-month-old toddlers: The Growing Up in Singapore Towards Healthy Outcomes (GUSTO) study. Public Health Nutr. 2019, 22, 1990-2000. [CrossRef] [PubMed]

48. Jung, C.-H.; Choi, K.M. Impact of high-carbohydrate diet on metabolic parameters in patients with Type 2 Diabetes. Nutrients 2017, 9, 322. [CrossRef] [PubMed]

49. Foterek, K.; Hilbig, A.; Kersting, M.; Alexy, U. Age and time trends in the diet of young children: Results of the DONALD study. Eur. J. Nutr. 2016, 55, 611-620. [CrossRef] [PubMed]

50. Castro, P.D.; Kearney, J.; Layte, R. A study of early complementary feeding determinants in the Republic of Ireland based on a cross-sectional analysis of the Growing Up in Ireland infant cohort. Public Health Nutr. 2015, 18, 292-302. [CrossRef]

51. Guthrie, J.F.; Anater, A.S.; Hampton, J.C.; Catellier, D.J.; Eldridge, A.L.; Johnson, W.L.; Quann, E.E. The special supplemental nutrition program for women, infants, and children is associated with several changes in nutrient intakes and food consumption patterns of participating infants and young children, 2008 compared with 2016. J. Nutr. 2020, 11, 2985-2993. [CrossRef]

52. Davis, K.E.; Li, X.; Adams-Huet, B.; Sandon, L. Infant feeding practices and dietary consumption of US infants and toddlers: National Health and Nutrition Examination Survey (NHANES) 2003-2012. Public Health Nutr. 2018, 21, 711-720. [CrossRef]

53. Marcelino, G.; Hiane, P.A.; Freitas, K.D.C.; Santana, L.F.; Pott, A.; Donadon, J.R.; Guimarães, R.D.C.A. Effects of olive oil and Its minor components on cardiovascular diseases, inflammation, and gut microbiota. Nutrients 2019, 11, 1826. [CrossRef]

54. Hay, G.; Trygg, K.; Whitelaw, A.; Johnston, C.; Refsum, H. Folate and cobalamin status in relation to diet in healthy 2-y-old children. Am. J. Clin. Nutr. 2011, 93, 727-735. [CrossRef]

55. Bailey, R.L.; Catellier, D.J.; Jun, S.; Dwyer, J.T.; Jacquier, E.F.; Anater, A.S.; Eldridge, A.L. Total usual nutrient intakes of US children (Under 48 Months): Findings from the Feeding Infants and Toddlers Study (FITS) 2016. J. Nutr. 2018, 148, 1557S-1566S. [CrossRef]

56. Gong, R.; Wang, Z.-P.; Wang, M.; Gao, L.-J.; Zhao, Z.-T. Effects of folic acid supplementation during different pregnancy periods and relationship with the other primary prevention measures to neural tube defects. J. Matern. Neonatal Med. 2016, 29, 3894-3901. [CrossRef]

57. Prietl, B.; Treiber, G.; Pieber, T.; Amrein, K. Vitamin D and immune function. Nutrients 2013, 5, 2502-2521. [CrossRef] [PubMed]

58. Akkermans, M.D.; van der Horst-Graat, J.M.; Eussen, S.R.B.M.; van Goudoever, J.B.; Brus, F. Iron and vitamin D deficiency in healthy young children in Western Europe despite current nutritional recommendations. J. Pediatr. Gastroenterol. Nutr. 2016, 62, 635-642. [CrossRef] [PubMed]

59. Brunner, T.A.; Casetti, L.; Haueter, P.; Müller, P.; Nydegger, A.; Spalinger, J. Nutrient intake of Swiss toddlers. Eur. J. Nutr. 2018, 57, 2489-2499. [CrossRef] [PubMed]

60. Manzano, A.S.; Rodriguez, B.; Piñeiro, R.; Nuñez, E.; Escrig, R.; Cabrera, L.; Calvo, C. Utilización de Vitamina D en Pediatria; Asociación Española de Pedriatría: Madrid, Spain, 2019.

61. Wang, Y.; Wu, Y.; Li, T.; Wang, X.; Zhu, C. Iron metabolism and brain development in premature infants. Front. Physiol. 2019, 10, 463-476. [CrossRef]

62. Walton, J.; Kehoe, L.; McNulty, B.A.; Nugent, A.P.; Flynn, A. Nutrient intakes and compliance with nutrient recommendations in children aged 1-4 years in Ireland. J. Hum. Nutr. Diet. 2017, 30, 665-676. [CrossRef]

63. Ziauddeen, N.; Rosi, A.; Del Rio, D.; Amoutzopoulos, B.; Nicholson, S.; Page, P.; Scazzina, F.; Brighenti, F.; Ray, S.; Mena, P. Dietary intake of (poly)phenols in children and adults: Cross-sectional analysis of UK National Diet and Nutrition Survey Rolling Programme (2008-2014). Eur. J. Nutr. 2019, 58, 3183-3198. [CrossRef] [PubMed]

64. Rossi, M.C.; Bassett, M.N.; Sammán, N.C. Dietary nutritional profile and phenolic compounds consumption in school children of highlands of Argentine Northwest. Food Chem. 2018, 238, 111-116. [CrossRef]

65. Rosi, A.; Mena, P.; Castello, F.; Del Rio, D.; Scazzina, F. Comprehensive dietary evaluation of Italian primary school children: Food consumption and intake of energy, nutrients and phenolic compounds. Int. J. Food Sci. Nutr. 2020, 21, 1-12. [CrossRef] 
66. Wisnuwardani, R.W.; De Henauw, S.; Androutsos, O.; Forsner, M.; Gottrand, F.; Huybrechts, I.; Knaze, V.; Kersting, M.; Le Donne, C.; Marcos, A.; et al. Estimated dietary intake of polyphenols in European adolescents: The HELENA study. Eur. J. Nutr. 2019, 58, 2345-2363. [CrossRef]

67. Stephen, A.M.; Champ, M.M.-J.; Cloran, S.J.; Fleith, M.; van Lieshout, L.; Mejborn, H.; Burley, V.J. Dietary fibre in Europe: Current state of knowledge on definitions, sources, recommendations, intakes and relationships to health. Nutr. Res. Rev. 2017, 30, 149-190. [CrossRef]

68. EFSA Panel on Dietetic Products, Nutrition, and Allergies (NDA). Scientific Opinion on Dietary Reference Values for carbohydrates and dietary fibre. EFSA J. 2010, 8, 1462.

69. Marriott, L.D.; Robinson, S.M.; Poole, J.; Borland, S.E.; Godfrey, K.M.; Law, C.M. What do babies eat? Evaluation of a food frequency questionnaire to assess the diets of infants aged 6 months. Public Health Nutr. 2007, 11, 751-756. [CrossRef] [PubMed] 